UDC 7.071.1:929 Infante F.

7.071.1:929 Gorjunova N.

7.01

https://doi.org/10.18485/ms_zmss.2021.100.33

\author{
Nicoletta Misler \\ Università di Napoli “L'Orientale", Naples, Italy \\ mislern@gmail.com \\ John E. Bowlt \\ University of Southern California. \\ Department of Slavic Languages and Literatures, \\ University of Southern California, Los Angeles, USA \\ bowlt@usc.edu
}

\title{
TRANSFIXED BY MERIDIANS OF DARKNESS: FRANTSISKO INFANTE AND NONNA GORIUNOVA
}

The authors comment on the genesis and evolution of the Artefact, an artistic concept and object developed by Moscow artists Frantsisko Infante and Nonna Goriunova. Divided into three sections, the article treats of basic concepts which inspire the artists to create their Artefacts, especially snow as an esthetic force and a natural ambience in which the artists install, photograph and then demolish the Artefacts (snow being a metaphor for absence or "nothing"), the notion of infinity vs. the falseness of geometric imposition and the Artefact as a symbol of this conflict - and the perception and notion of the state of "between" as in twilight, a condition which the artists explore in their latest series of artifacts called "Towards Night".

Keywords: Frantsisko Infante, Nonna Goriunova, ARGO, Stroganov Institute of Decorative and Applied Arts, Artefacts, concept of zero, concept of infinity, twilight zone, Malevich, snow as artistic medium, Aleksandr Blok, Naum Gabo, Anton Pevsner.

The three cameos below concern the two Moscow artists, Frantsisko Infante (b. 1943) and Nonna Goriunova (b. 1944) (Ill. 1), long celebrated for their land-art installations called "Artefacts" (Ill. 2). A husband-and wife team, Infante and Goriunova place minimal structures of wire, cord and plastic in natural environments of water, snow, earth, sand, stone and flora, photograph and then dismantle, leaving the ambience intact. As a laboratory of forms, the Artefacts evoke an intermediate space and an intermediate silence - a twilight zone wherein, albeit momentarily, outlines dissolve, light diffuses and time freezes.

Graduating from the Moscow Middle Art School of the Surikov Art Institute at age fourteen, Infante enrolled at the Stroganov Institute of Decorative and Applied Arts in Moscow where he studied until 1966, manifesting a particular interest in geometric and constructive art. In 1964, aware of European and Amer- 


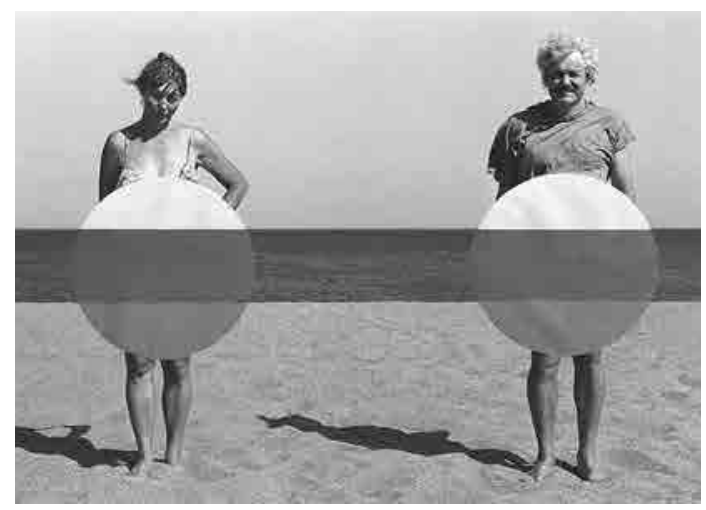

Ill. 1. Self-photograph: Nonna Goriunova and Frantsisko Infante during installation of Artefacts on the beach in Sotogrande (Andalusia), Spain, 1992

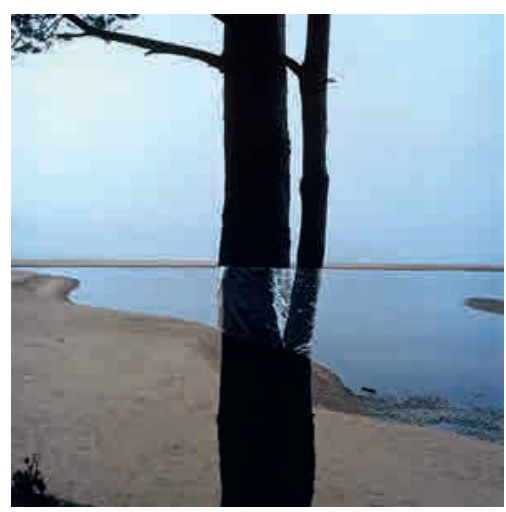

Ill. 2. Fragment of Nature. Artefact from the cycle Land-Art, 1984, polyethylene and mirror foil, Saulkrasti on the Baltic Sea, Latvia

ican kinetic art, Infante, Goriunova and other artists established the group Dvizhenie [Movement] and in 1967 constructed the Soviet Union's first kinetic artifact, "Galaktika", for the Exhibition of Achievements of the National Economy in Moscow. Although Infante and Goriunova opposed the conventions of Socialist Realism, the Artefacts appealed to scientists who helped display them in "alternative spaces" such as the Kurchatov Institute of Atomic Energy in Moscow in 1966. In 1970 together with engineer Valerii Osipov, Infante and Goriunova founded ARGO [Author Working Group], designing artificial systems parallel to natural phenomena and creating a kinetic ambience called "Sound and Light"for the "Chemistry-70" exhibition in Moscow and constructing a kinetic installation for the exhibition "Link-1975" in Moscow's Sokol'niki Park. The Artefacts engender reflectivity, ambiguity, and interactivity, often recalling the geometric traditions of the Russian avant-garde, particularly, Kazimir Malevich and Vladimir Tatlin. In the Artefacts, Infante and Goriunova endeavour to juxtapose the natural with the artificial - as in the "Spiral" cycle of 1965, in which the unending impulse of the spiral oscillates with the geometry of vertical and horizontal. In 1996 Infante received the Russian State Prize for Art.

Together with Goriunova, Infante continues to evolve the concept of the Artefact through installations, exhibitions and theoretical treatises. The two artists have been invited to many national and international exhibitions and are represented in major public and private collections worldwide. Infante and Goriunova have two sons, Pakhito and Platon, both artists, and have eight grandchildren - Efrosin'ia, Ekaterina, Evdokiia, Pelageia, Polina, Serafim, Tikhon, and Timofei - all of them manifesting visual talent.

The three chapters below advance both in calendar time (treating of three subsequent phases in the life and work of the two artists, i.e. from 2008 through 2017 to 2021) and in thematic direction: "Meridians of Snow" treats of snow as an esthetic medium as well as a philosophical quest for absence, zero and envi- 


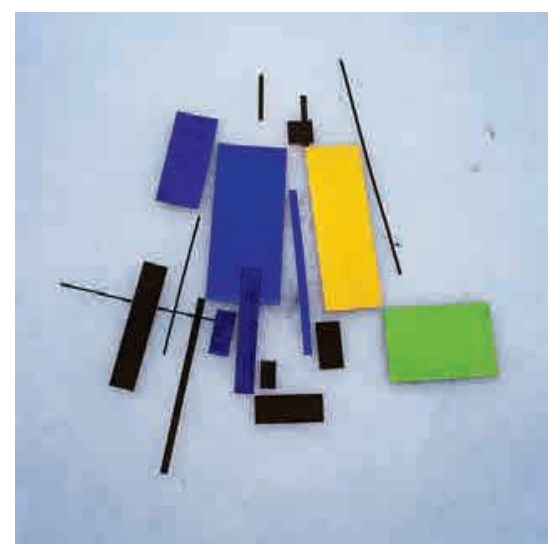

Ill. 3. Artefact from the cycle Suprematist Games, 1968, snow, tempera on sheets of cardboard

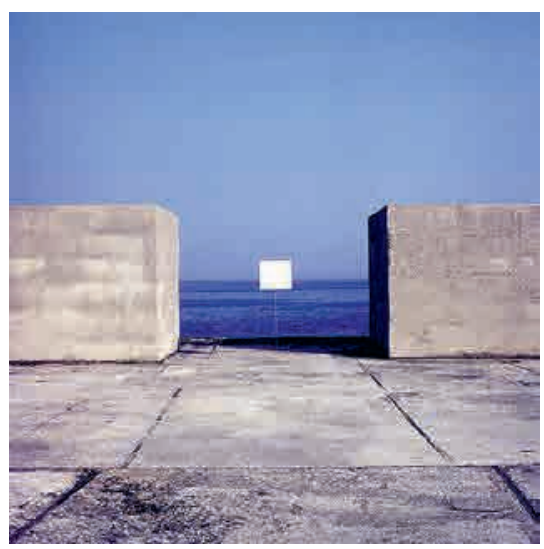

Ill. 4. Artefact from the cycle Additions, 1983, cement cubes, mirror, Gurzuf on the Black Sea, Crimea

ronmental purity. "Transfixed by an Eerie Closeness" focuses on the notion of the veil or curtain which separates "here" from "there", a notion which Infante and Goriunova induce into the Artefacts which, in turn, become metaphors for this transcendance. "Because Darkness Will Cover the Earth", however, touches on the condition of nightfall and on the pregnant silence which heralds the advent of the moon and stars, now accompanied by the electric glow of the Artefacts.

\section{Meridians of Snow ${ }^{1}$}

Whilst the snow came down silently on the end of the world, It was as if the place had been totally forgotten

(Orhan Pamuk, Snow, 2002)

Since 1968, when Infante installed his first Suprematist "game" and he and Goriunova embarked upon their great artifactual voyage, snow has been a common and constant denominator of the consistency, mission and expression of their artistic creativity (Ill. 3). Without the element of snow, Infante's and Goriunova's experiments in light, color, form and texture would be unthinkable - so much so that today, with the dramatic decrease in Moscow's snowfall as a result of global warming, Infante and Goriunova ponder how they will come to terms with the esthetic challenge of a vanishing technical and natural medium. True, they also address other natural phenomena to transmit their ideas such as stone, wood, sky and water in installations such as the cycle called "Additions" of 1983 (Ill. 4), but snow remains a principal creative agent, unique in its spectral integration, luminosity, granulation and impermanence. As Infante wrote in his "Introduction

1 This text, "Meridiany snega", first appeared in Russian in the catalogue of the exhibition "Snezhnyi meridian" [Snow Meridian] held at the Polina Lobachevskaia Gallery in the Chekhov House, Moscow, in 2008. 


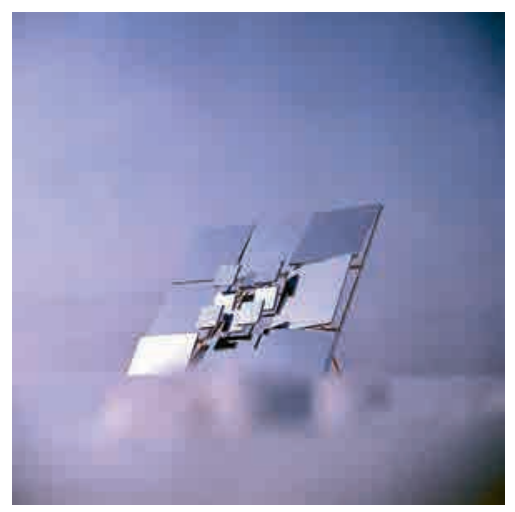

Ill. 5. Artefact from the cycle Winter Square, 1977, wood, metallized polyethylene foil, near Moscow

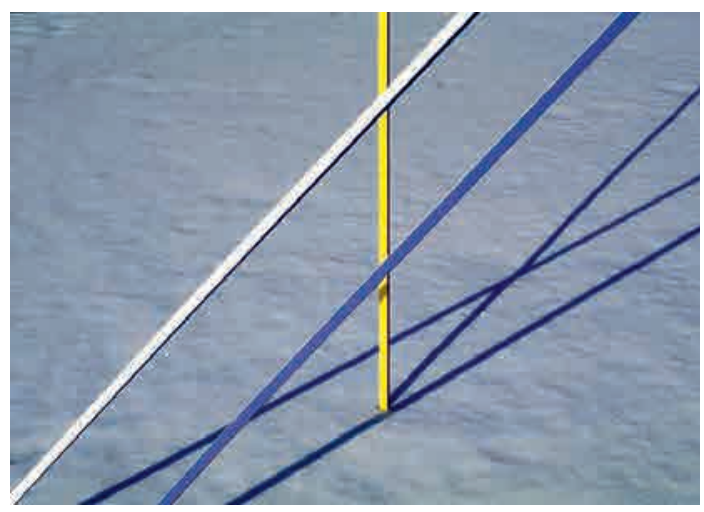

Ill. 6. Artefact from the cycle Lines, 2003, snow, wooden slats painted with tempera, Sparrow Hills, Moscow

to the Artificial Art-action": "The world of form is created by the action of the TRANS-LIMITATIONAL" (Infante 1999: 55).

Of course, Infante and Goriunova are not the first Russian artists to investigate the snowy plain or its pictorial extensions, the white canvas, the sheet of paper and the slab of marble, as an esthetic exercise. Kazimir Malevich's "White on White" series of 1917-18 is an obvious precedent, but other painters of the Russian avant-garde also experimented with the "colour" white, from Vasilii Kandinsky with his "White Border" to Pavel Filonov with his "White Painting" (which, however, is not white). Whether these artists were appealing to the force of Nirvana (as in the case of Nikolai Kul'bin) or undertaking a pyrotechnical display of device (as in the case of David Shterenberg with his white still-lives), the tabula rasa elicits immediate connections with sacred light, moral purity, invisibility and "nothingness", qualities which, inevitably, Infante's and Goriunova's Artefacts in the snow such as "Winter Square" (1977) also generate (Ill. 5).

Inasmuch as the fundamental dictate of the Artefact is to remove all material traces from the field of enactment and to leave nature intact after the work has been photographed and disassembled, snow emerges as the perfect metaphor for the Artefact itself. Like the constructed Artefact, snow is momentary in its physical presence, transient in its beauty and silent in its engagement with the ambience and yet is replete with a patterned artistry of snowflakes, variegated textures and dazzling expanse. As Infante asserts in his essay "On my Concept of the Artefact": "Nature possesses the function of infinity, while the artificial object-cum-artefact is a symbol of the technological part of the world" (Infante 1999b: 75).

There are many reasons why Infante and Goriunova turn to snow as a central medium. A monochromatic surface, snow constitutes an effective ground for the superimposition of concrete elements, horizontal and vertical, convex and concave (cf. "Suprematist Games" of 1968 and "Lines" of 2003) (Ills. 3, 6). More- 


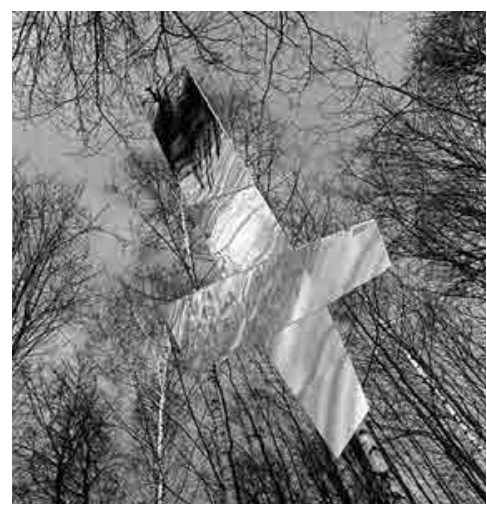

Ill. 7. Artefact from the cycle Thresholds of Curved Space, 1979, curved mirror surfaces in the form of a cross and wooden frames of polyethylene foil, snow, forest, sky, Sparrow Hills, Moscow

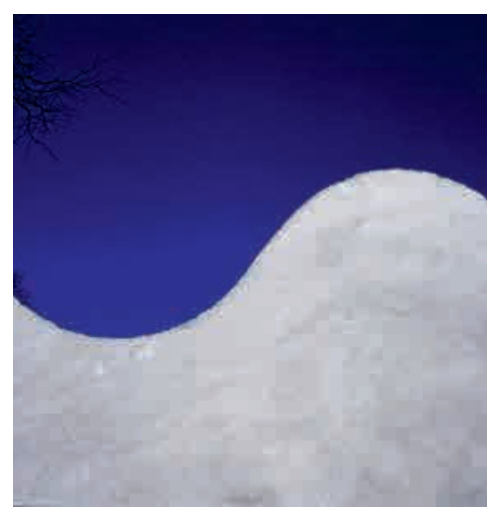

I11. 9. Artefact from the cycle White Constructions, 1996, snow, Sparrow Hills, Moscow

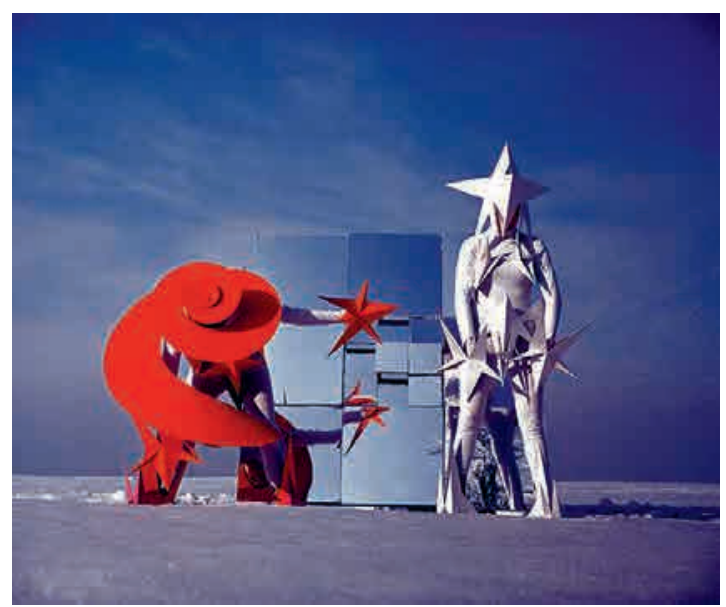

Ill. 8. Artefact from the cycle Play of Gestures, 1967, human figures, snow, tempera on cardboard, electric light-bulbs, near Moscow

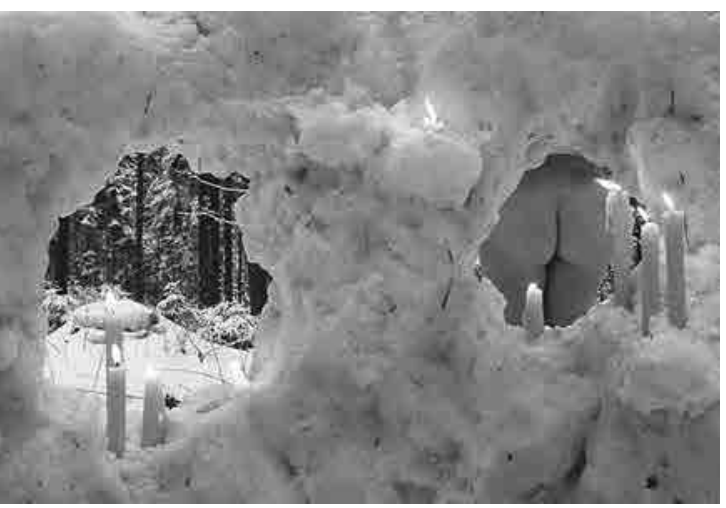

Ill. 10. Artefact from the cycle Spontaneous Games in Nature, 1968, tempera on cardboard, metallized polyethylene foil, near Moscow

over, snow can also constitute a highly textured and refractive ground, charging a composition or construction with variegation and energy ("Thresholds of Curved Space" of 1979) (Ill. 7). Infante and Goriunova also use snow to build structures, sometimes figurative (such as the robotic "Game of Gestures" of 1967) (Ill. 8), often abstract (such as the "White Constructions" of 1996) (Ill. 9), or to establish transverse connections between spectator and spectacle ("Spontaneous Games in Nature" of 1968) (Ill. 10). Ultimately, Infante and Goriunova, privy to the divine spirit, simply remind us that the Artefact, supreme or profane, is but a fleeting presence between the "Grand Néant" preceding alpha and following omega and that it denotes "nothing" in the same way as the Suprematist monochrome. 


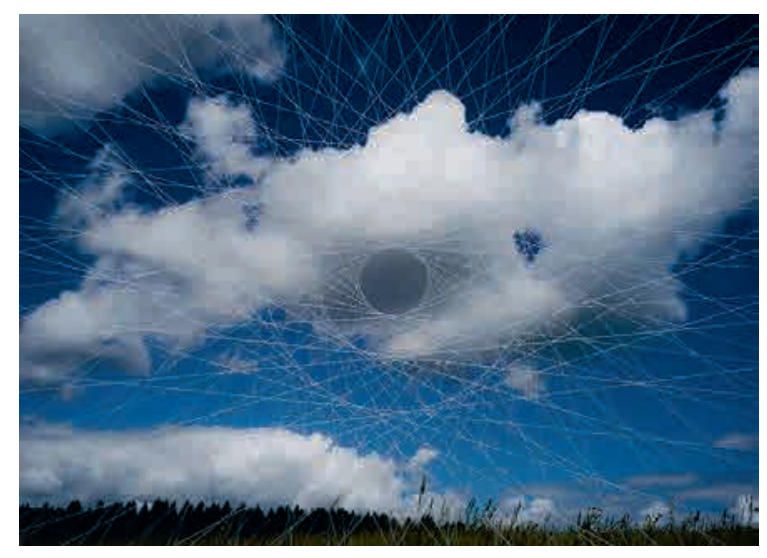

Ill. 11. Artefact from the cycle Lighter Spaces, 2017, sky, polyethylene and cotton thread, Zhiganovo, Moscow District

Wherein lies the essential meaning of Infante's and Goriunova's geometric shapes cast upon a snowy expanse? While paying homage to Malevich's Suprematist paintings with their constant white background (for Malevich white was the symbol of infinity), Infante and Goriunova are also confirming that simplicity and reduction in the form of silence, invisibility, impalpability and transience are the vital components of the work of art. Put differently, the sparser the material substance, the stronger the effect, echoing Andrei Belyi's contention that the highest form of art is music (immaterial) and the lowest architecture (material). In this respect, Infante and Goriunova are at odds with the main tendency of contemporary Western society towards material plenitude - a rampant consumerism which is occupying and commodifying all free space and turning everyday life into a gigantic shopping-mall.

That this physical rapaciousness, so patent in the new Moscow, is contributing to ecological disaster is also immanent to Infante's and Goriunova's preoccupation with snow: not only is snow becoming a rarer phenomenon in Moscow, as the ice-caps melt and diabolical traffic increases the local temperature, but also the dazzling whiteness and the ultramarine sky of Infante's first snow Artefacts such as the Suprematist Games are already replaced by soiled surface and opaque sky. Infante and Goriunova are warning us that not only is the snow vanishing, but also that the very air and sky are being polluted and destroyed by the emissions of our social obesity. On this level the latest Artefacts, still beautiful in their esthetic combinations, are also a documentary testimony to imminent catastrophe.

True, not all hope is abandoned, because Infante and Goriunova still manage to identify oases of purity which they incorporate into their Artefacts - the stones of a remote village, the virgin forest, the maritime horizon and the Artefacts themselves as independent units. Even so, as we look at Infante's and Goriunova's prismatic structures of the 1960s and 1970s such as the "Suprematist 


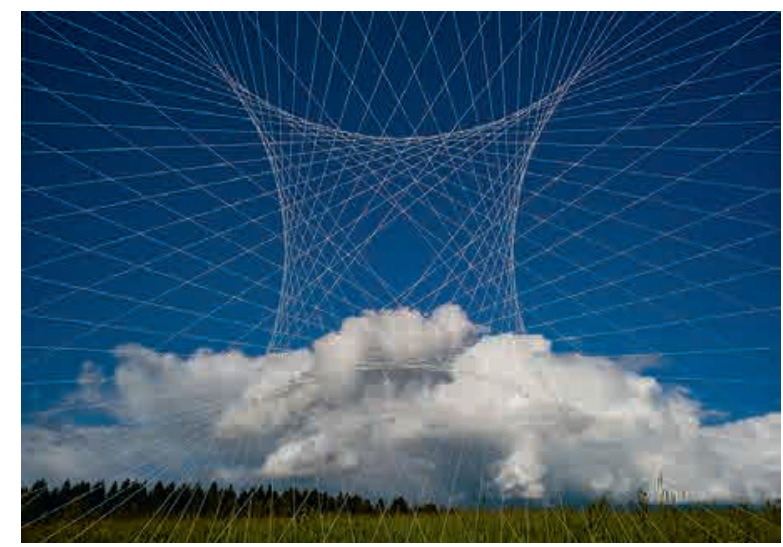

I11. 12. Artefact from the cycle Lighter Spaces, 2017, sky, polyethylene and cotton thread, Zhiganovo, Moscow District

Games", we are bound to experience a strong nostalgia for a world which was still linked organically to the primaeval and the pristine. The snow of the Artefacts covers the ugliness of civilization, it silences the noise of humans and machines and via the inscrutable, but perfect geometry of snowflakes reminds us of the superior, mysterious harmony still directing the meridian, the firmament and the cosmos.

\section{Transfixed by an Eerie Closeness ${ }^{2}$}

And transfixed by an eerie closeness, I look beyond the dark veil, And see a shore enchanted

And an enchanted distance.

(Aleksandr Blok: “The Stranger”. 1906)

One of the most enigmatic qualities of our power of perception is that it tends to reduce material reality to geometric units and configurations of those units and to impose regularity upon irregularity and rational order upon what seems to be capricious disorder. Hence, for example, our codices of laws, rules of navigation, rectangular doors and windows, canonical perspective and proportion, symmetry of outward appearance and an arithmetic based on $2+2=4$, although occasional individuals, especially creative writers and artists, from Fedor Dostoevsky to Jackson Pollock, may fight against this dictate. However, all too often, we accept this geometry at its face value, equating it with the "real thing", ignoring the primordial chaos beyond, happy that we are tending a garden of

2 This text, "Zakovannyi strannoi blizost'iu", first appeared in Russian in the catalogue of the exhibition «Legkhie prostranstva» [Lighter Spaces] held at the Krokin Gallery, Moscow, between December, 2017 and January, 2018. 


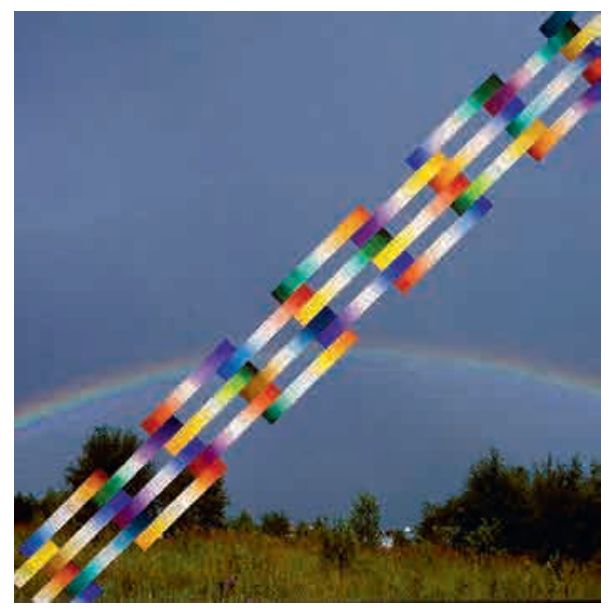

Ill. 13. Artefact from the cycle In the Heavens and the Clouds, 2008, sky, tempera on paper, wooden slats, thread, Zhiganovo, Moscow District

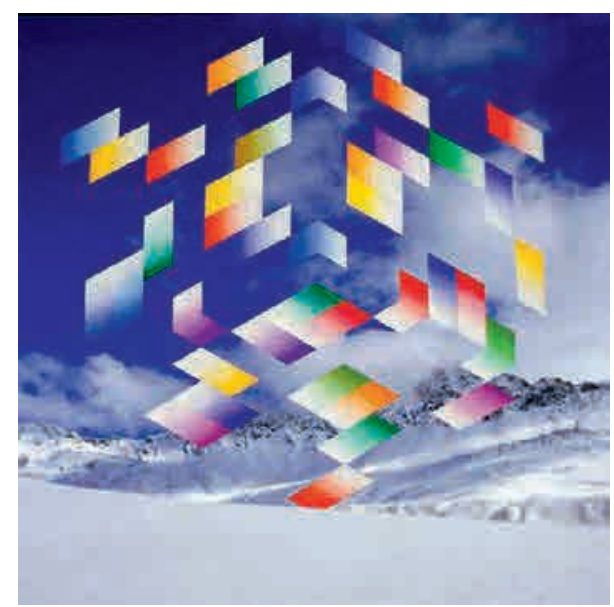

Ill. 14. Artefact from the cycle Alpine Snow, 2008-2009, snow, tempera on paper, shrouds of polyethylene thread fastened with wooden slats, Valbella, Switzerland

topiaries rather than a jungle of unruly foliage. Perhaps that is what the Symbolist poet and philosopher Andrei Belyi had in mind when he declared that "rhythm is the force of life, meter its denial" (Belyj 1910: 254), indicating that meter is the garden of imposed convention while rhythm is the Matto Grosso - and ultimate driving-force - of the universe.

Infante and Goriunova remind us that geometric imposition can, indeed, be misleading and mendacious and that calendar time is not the same as cosmic time. The imposition may gratify the senses, bolster self-confidence and provide an illusion of control, but, in essence, the ordering of disorder is merely a veil or magic spell cast to deflect attention from uncomfortable concepts such as infinity, shapelessness and boundlessness. This becomes especially evident in the cycle of Artefacts called "Lighter Spaces" (2017) (Ills. 11, 12) with their interplay of, as it were, auditorium and proscenium divided by the drop curtain — or veil of aerial filaments and interweaving screens.

It is the juxtaposition of façade and depth which forms the esthetic and philosophical denominator common to "Lighter Spaces", a formula which seems to illustrate Naum Gabo's and Anton Pevsner's "Realist Manifesto" of 1920: "We renounce volume as a pictorial and plastic form of space; one cannot measure space in volumes, as one cannot measure liquid in yards: look at our real space what is it if not one continuous depth? We affirm DEPTH as the only pictorial and plastic form of space" (Gabo, Pevsner 1920).

If many of the previous Artefacts were momentary installations in land, water and air (metal foil encircling trees, structures mounted on snow, artificial rainbows set against the sky) (Ill. 13), the new series begs the very question of ambivalence or, rather, of constant interaction between perfect, but artificial, 


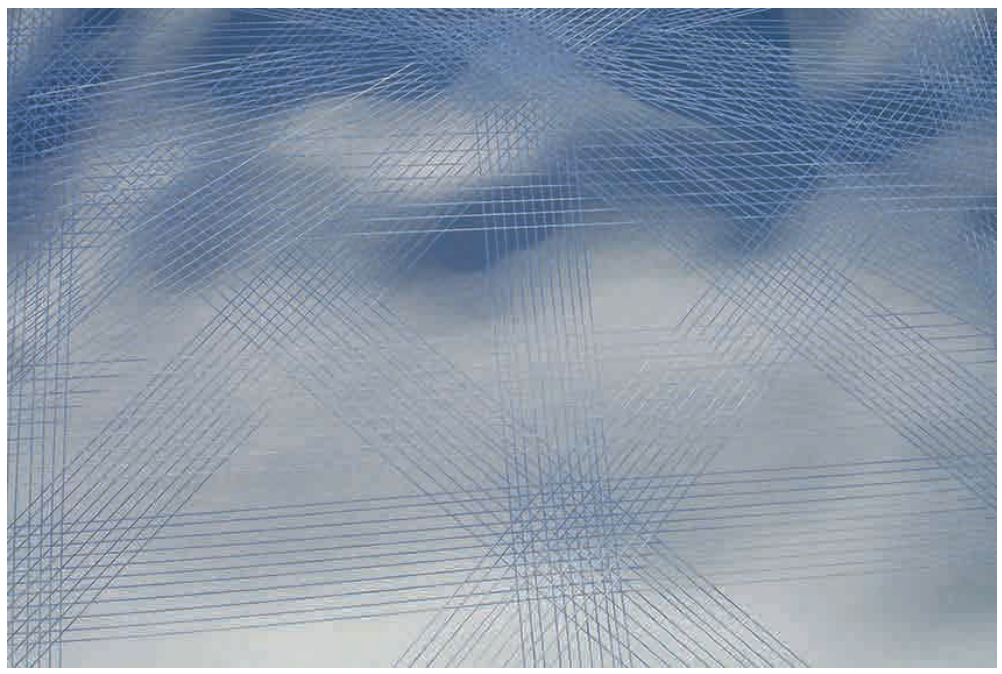

Ill. 15. Artefact from the cycle Strings, 2013, snow, wooden slats, different coloured threads, Moscow

forms, and perfect, but natural, shapes. To this end, Infante and Goriunova make frequent recourse to the concept of the grid and the net (Ill. 14), a chequered sequence which elicits the image of entry and exit and of imminent transport from "here" to "there", emphasizing that the higher, lighter and elemental space - where angels tread - is beyond the grid and that our everyday regime is but a pathetic travesty of the immense and unfathomable firmament beyond.

However, as with all the Artefacts, Infante and Goriunova impose no compunction upon their visual resolutions: there is no ideological agenda, no overt temptation, no obvious command to raise the veil and travel to the enchanted shore. "Take it, or leave it", seems to be the message, meaning that we can cruise the sensual highway through the coloured configurations and enjoy the brilliant plays of light and surrogate delight in peeping at, but not entering into, the "lighter space". In this way, the Artefacts defend the shapely viewer from shapelessness - rather like the luxury liner which anchors off the wild Amazon whither its tame passengers, however, do not embark.

So as to reinforce this tension between the dark veil and the enchanted shore, Infante and Goriunova construct hyperbole or, rather, the hyperbolas, dynamic shapes of tensile coils which both keep the Artefact intact and provide it with elasticity and oscillation, qualities which, once again, prompt the viewer to hesitate - and to remain transfixed on the threshold separating here from there. The hyperbola, essentially, a spiralic, symmetrical and open curve formed by the intersection of a circular cone with a plane at a smaller angle (Ill. 15), also constitutes a metaphor for infinity and, therefore, for the timelessness - or lighter space - which, manifestly, lies on the other side of the Artefact. The hyperbola is a major unit in Infante's artistic vocabulary, for even the early structures 


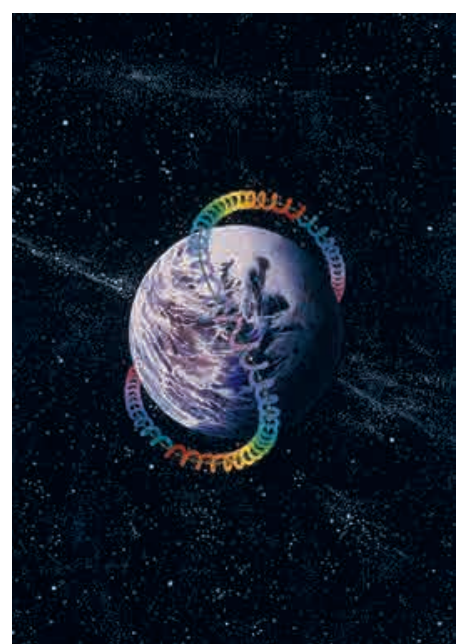

Ill. 16. Necklace (Spiral Encircling the Earth. View from the Cosmos). From the cycle Projects of Autonomous Artificial Systems in Cosmic Space, 1971, tempera and hardboard on paper, $78 \times 46$

such as the project for a necklace of lights intended to encircle the Earth (1971) (Ill. 16) already bore the genesis of the hyperbola. Captivated thereby, the viewer glimpses chaos and experiences entropy, but, fearful, still continues to glance back to the world of reason and sobriety. Indeed, "Lighter Spaces" are so elegant and gracious in the crochet lightness of their colours, forms and textures that they tempt us to go backwards rather than forwards, even if the call of the wild is almost irresistible.

The grid system of these new Artefacts plays a double role, because at once it reveals the beyond, whether that beyond be a cloud, blue sky, water or vegetation - and veils all those things (Ill. 17). The result is a half-truth, an allusion and an innuendo, because until we advance into the wilderness we cannot understand its force, energy and lighter space. Even so, for some, "Lighter Spaces" may be merely beautiful divertissements set against the elements; for others, they may be sirens beckoning to the vault of heavens; and for yet others, tragically, the here and there remain parts of the same limbo: "Nothing will change, There's no way out", wrote Blok in 1912. ${ }^{3}$ Nonetheless, "Lighter Spaces" still carry a saving grace which transcends territorial directives - and that is their technical perfection, their harmonious assembly of form, colour, rhythm, weight and gravity and their strong esthetic presence. Infante and Goriunova seem to be proposing that the Artefact, therefore, may be regarded both as a reassertion of the here and now and as a bridge to celestial spheres — but also as an independent work of art, untrammeled by any of these prerogatives. Therein lies the delicate permanence and secret majesty of "Lighter Spaces".

\section{Because Darkness Will Cover the Earth ${ }^{4}$}

Just when our world is plunged into the darkness of doubt as fever advances across the wasteland of our civilization, the artefacts of "Towards Night" (2020-2021) (Ills. 18-21) shine boldly, offering a glimmer of hope and a new radiance. Metaphors of enlightenment, these coloured beacons provide a respite from the sinister forces which inhabit the night — just as a 24-hour truck-stop does in Death Valley, California.

3 Blok Aleksandr. "Noch', ulitsa, fonar', apteka", 1912.

4 This text, "Ibo t'ma pokroet zemliu", first appeared in Russian in the catalogue of the exhibition "K nochi" [Towards Night] held at the Alina Pinskaia Gallery, Moscow, between February and April, 2021. The title is from Isaiah 60.2. 


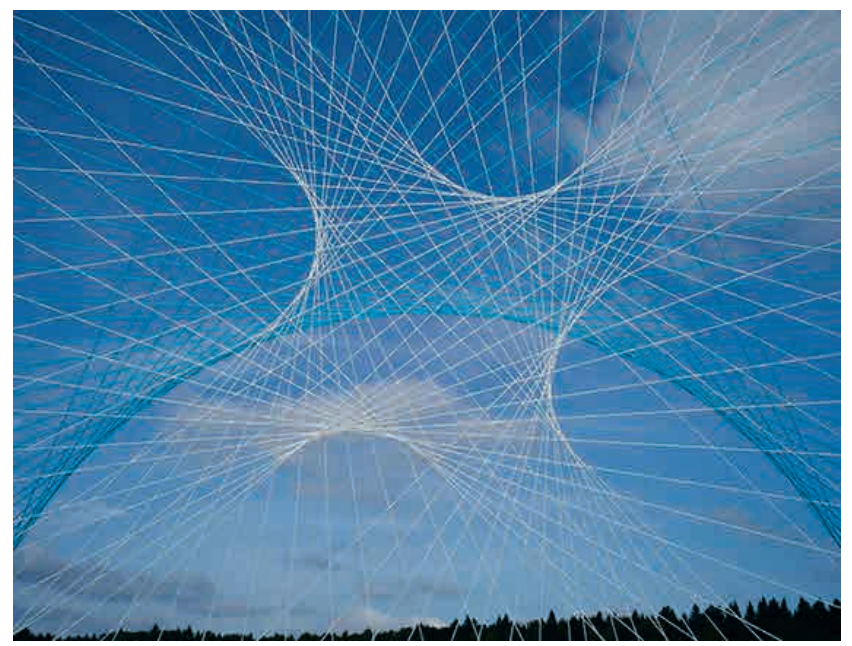

Ill. 17. Artefact from the cycle Lighter Spaces, 2017, sky, polyethylene and cotton thread, Zhiganovo, Moscow District

We fear nightfall because at night boundaries vanish, space becomes nonEuclidean and the simple progression from A to B no longer holds sway. Bereft of territorial orientation, night hyperbolizes sources of both light (a candlelight can be visible from many kilometers away) and sound (the reverberating hoot of the owl) as if demanding a new sensory perception, perhaps even a dérèglement de tous les sens. Shadows of that other mode - intuition, instinct, the sixth sense - still retain from a primordial condition, even if our current cult of light pollution is destroying the intrinsic alertness whereby our forgotten ancestors traversed black forests and uncharted seas. In fact, "Towards Night" poses the fundamental question as to why we now accept day, not night, as the time of revelation, forgetting that night, with its untamed vastness, may be closer to the Truth than the high definitions of everyday. At the same time, night - or, rather, darkness - still holds an ambivalent attraction, for who can resist the beguile of darkest Africa, the dark side of the moon or the Dark Ages?

"Towards Night" does not point to an alternative route, for it has no fixed anchorage, it is a moveable feast which, as is often the case with Infante's Artefacts, can be erected and demolished at any point, virtually without beginning and end. Like the mirage in the desert, here is a coloured Lorelei, a beautiful illusion which, as a bolt of lightning against the night sky, illumines only for an instant. But Towards Night also impresses a temporary mental order upon what appears to be a natural chaos: here are rigorous geometric units, calculated and structured with mathematical precision, which function and stand steadfast while at loggerheads with the looseness of the night, eliciting the paradox of a nocturnal rainbow. At this point we are on the threshold of a fairy-tale with its appurtenances of sudden transformation, omens and wizardry where witches haunt dark forests and monsters come out at night. After all, conditioned to accept night 

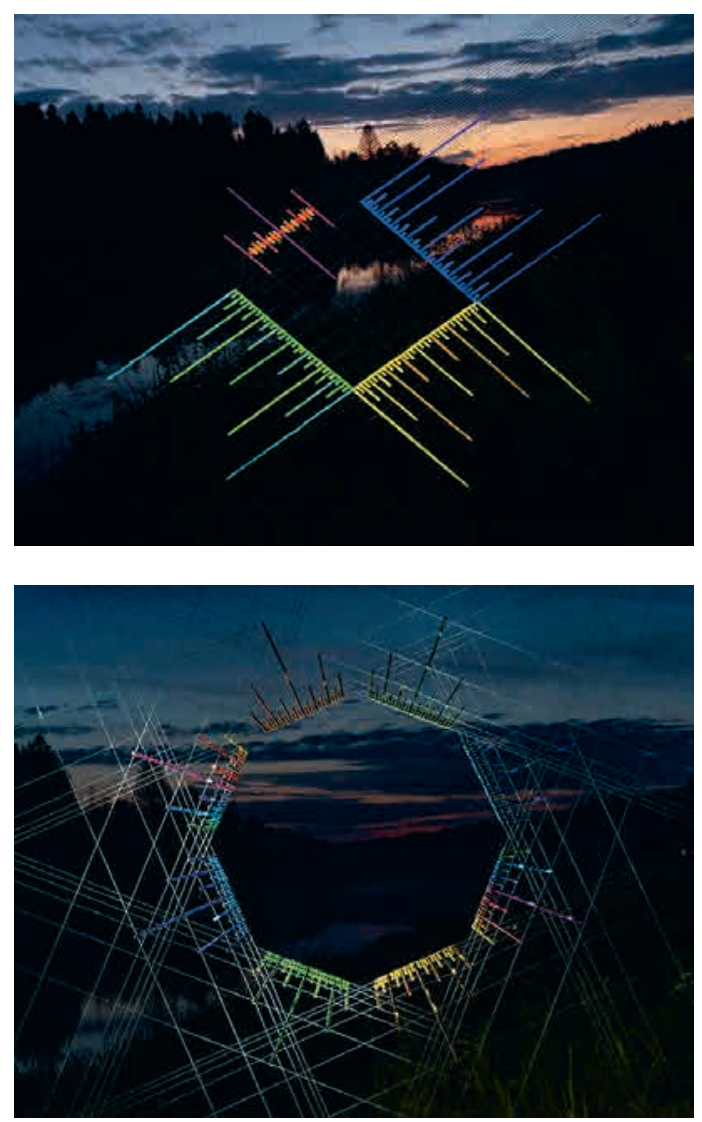

Ills. 18, 19. Artefact from the cycle Towards Night, 2020, natural forms by night, artificial objects of coloured shreds of paper, threads stretched on wooden frame, electric light, Zhiganovo, Moscow District as the abode of evil and malcontent, we regard night as the preface to day, when hope replaces despair and lightness density. "Towards Night" forces us to question that dichotomy and to wonder whether night may not be as enlightening, as edifying, as day.

Certainly, the Artefacts of "Towards Night" offer visual gratification through their rich gamut of red, yellow, blue and green, monochromes and light effects acting upon varying quadrilaterals and circles, but they are neither narrative, nor ideological, and like glowworms or fire-flies at twilight or phosphorescent fish in the ocean depths, they carry no geographical imperative. Beyond metaphorical asset, perhaps their highest value is impermanence, because, constructed, photographed and then removed, "Towards Night" neither intrudes, nor interferes, leaving nature intact and, unlike the metropolis, refuses to turn night into a parody of day. On this level, the Artefacts resemble meteors or shooting stars, brilliant as they seem to speed across the heavens only to vanish, consumed, in darkness. Likewise, but unlike low flying aeroplanes or the artificial suns of city lights, the Artefacts are also, therefore, unobtrusive, merging with their element and their ambience, the night, just as Infante's and Goriunova's previous Artefacts did with snow and water. On this level, night itself also becomes a component of the mixed media.

If the twilight and night-time modify shapes, time and distance, so the cycle of "Towards Night" also functions as a continuum of formal alteration — for the spiral (the common denominator of Infante's theory and practice) has now become a flattened circle, the earlier "Suprematist Games" (Ill. 3) now flying trapezes. At the same time, these Artefacts are germinating potential sign systems, now resembling a musical score, now the graph of an electro-cardiogram, now a consumer bar-code. Here are linguistic compendia which transform their mes- 
sages as the pink of sunset turns to burnt orange, the vortex of a cloud impacts their geometry or the green of foliage and the glistening water yield to the encroaching shadows of the night. Yet the Artefacts are also living entities, because, even if attached by wires and hawsers to a static frame (measuring on average $140 \times 200 \mathrm{cms}$.), they also change form and colour depending upon the hour and the degree of darkness. The result is a ceaseless struggle between solidity and liquidity, a struggle often pitched at twilight which, in itself, is the juxtaposition of day and night, here and there.

At this juncture, the Artefacts of "Towards Night" bring to mind another masterpiece bearing the same title, i. e. Mikhail Vrubel's "Towards Night" of 1900 (State Tretiakov Gallery, Moscow). Painted at the dawn of a new century and illumined by the setting sun, Vrubel's picture also evokes a moment of hesitation, of uncertain relationships
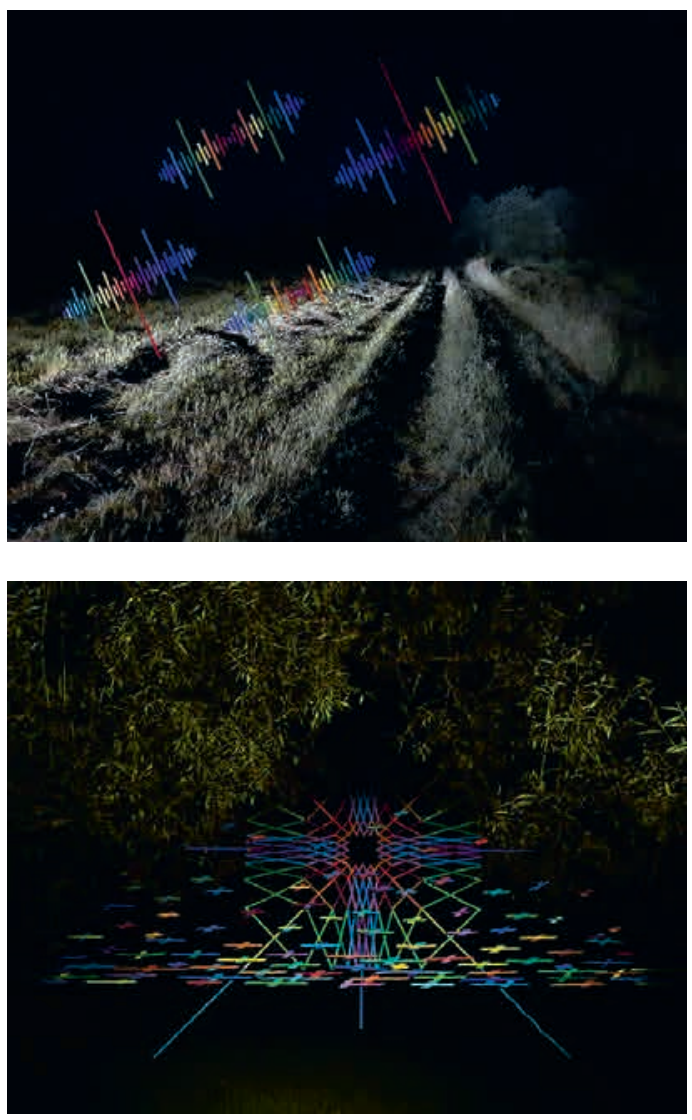

Ills. 20, 21. Artefact from the cycle Towards Night, 2020, natural forms by night, artificial objects of coloured shreds of paper, threads stretched on wooden frame, electric light, Zhiganovo, Moscow District

between fauna and flora, wherein contours and perimeters are being eroded by the stealth of darkness. Of course, Vrubel's "Towards Night", ambiguous and divisive, expresses the Apocalyptic moment between the dusk of the 19th century and daybreak of the 20th, a mood recaptured in the Infante-Goriunova cycle, also poised on the edge of sickness and sanity. Vrubel' - and Infante - erode perimeters, imagined or real, challenging us to shift viewpoints and question boundaries

If the Artefacts of "Towards Night", taut and tensile, produce the impression of mechanical perfection, closer scrutiny reveals the human manipulation which built them, i.e. the intricate mesh of wires which have been clasped to the frames to support the actual constructions and the sources of electricity which illumine them. Here is a rare occasion, a momentary innuendo, when Infante and Goriunova allow the viewer to discern the actual structure supporting the Artefact and its simultaneous reliance upon Nature, the human and the technological, and to 
feel the tension between the forms heaven-bound and the metal restraints which hold them back. For a moment a demiurge disturbs nightfall, creating kaleidoscopic planimetries and echoing, as it were, the solitude of a more ancient and Romantic night: "Within the quiet of night I am alone"5 — and returning us once again to the fundamental dilemma posed and illuminated by Infante's cycle: However much we try to impose our will upon the night, eventually darkness will cover the Earth, surrendering us to the absence whence we came.

\section{REFERENCES}

Belyi Andrej. "Lirika i eksperiment”. Belyj Andrej. Simvolizm. Moskva: Musaget, 1910.

Gabo Naum, Pevsner [Pevzner] Anton. Realisticheskij manifest. Moskva, 1920.

Infante Francisko. "Vvedenie k iskusstvennomu ARTdeistviju". Infante Francisko. Monografiya. Moskva: State Collection and Contemporary Art and State Center of Contemporary Art, 1999a.

Infante Francisko. "O svoej koncepcii artefakta". Infante Francisko. Monografiya. Moskva: State Collection and Contemporary Art and State Center of Contemporary Art,1999b.

Николета Мислер, Џон Боулт

ПРЕОБРАЖЕНИ МЕРИДИЈАНИМА ТАМЕ: ФРАНЦИСКО ИНФАНТЕ И НОНА ГОРЈУНОВА

Резиме

У овом раду аутори коментаришу генезу и еволуцију артефаката, уметничких концепата и објеката, коју су развили московски уметници Франциско Инфанте и Нона Горјунова. Подељен у три одељка, чланак се бави основним идејама које инспиришу уметнике да стварају уметничка дела, посебно снегом као естетском силом и природним амбијентом у ком уметници постављају, фотографишу, а затим и уништавају своја уметничка дела (снег представља метафору за одсуство или „ништа“), али и представом о бесконачности насупрот нетачности геометријске представе и артефактом као симболом овог конфликта - и перцепцијом и представом о појму „између“, који се налази у зони сумрака, односно у стању које уметници истражују у њиховој најновијој серији артефаката под називом „Приближавајући се ноћи““.

Кључне речи: Франциско Инфанте, Нона Горјунова, АРГО, Институт Строганова за декоративну и примењену уметност, артефакта, концепт нуле, концепт бесконачности, зона сумрака, Маљевич, снег као уметнички медијум, Александар Блок, Наум Габо, Антон Певзнер.

5 Lermontov Mihail. "Noch” (1830). 